\title{
PENERAPAN PIDANA UANG PENGGANTI KEPADA KORPORASI DALAM PERKARA KORUPSI DEMI PEMULIHAN KERUGIAN KEUANGAN NEGARA
}

\author{
(Implementation of Substitute Money Penalty to Corporation in Corruption Case \\ for Recovery the State's Financial Losses) \\ Budi Suhariyanto \\ Pusat Penelitian dan Pengembangan Hukum dan Peradilan MA-RI \\ Jl. Jend. Ahmad Yani Kav.58, Jakarta Pusat, Indonesia \\ Email: penelitihukumma@gmail.com
}

Naskah diterima: 12 Februari 2018; revisi: 3 April 2018; disetujui: 16 April 2018

\begin{abstract}
Abstrak
Muncul persoalan dalam praktik dimana korporasi tanpa dijadikan terdakwa tetapi turut dituntut dan dipidana untuk membayar uang pengganti akibat tindak pidana korupsi yang dilakukan pengurusnya. Alasan turut dipidananya tersebut karena hasil korupsi masuk ke dalam kekayaan dan aset korporasi sehingga patut untuk dituntutkan uang pengganti agar kerugian keuangan Negara menjadi terpulihkan. Namun tidak semua hakim sependapat dengan alasan tersebut mengingat tidak terjadi due process of law dalam hal pembelaan korporasi. Menarik dipermasalahkan yaitu bagaimanakah eksistensi dan penerapan pidana uang pengganti kepada korporasi dalam perkara korupsi serta implikasinya bagi pemulihan kerugian keuangan Negara? Untuk menjawab permasalahan tersebut digunakan metode penelitian hukum normatif dengan pendekatan perundang-undangan dan pendekatan kasus. Diaturnya pidana uang pengganti bertujuan untuk pemulihan kerugian keuangan Negara akibat tindak pidana korupsi. Adalah tidak adil jika pidana uang pengganti dijatuhkan kepada pengurus bilamana hasil korupsi itu senyatanya ditampung oleh korporasinya. Diperlukan kesepakatan dan pedoman untuk mengakhiri polemik diantara hakim Pengadilan Tipikor tentang dapatnya pidana uang pengganti dijatuhkan kepada korporasi meskipun tanpa dijadikan Terdakwa demi pemulihan kerugian keuangan Negara.
\end{abstract}

Kata Kunci: uang pengganti, korporasi, kerugian negara

\begin{abstract}
There is a problem in the practice where a the corporation is prosecuted and convicted to pay the substitute money due to the corruption committed by the corporate management without being the defendant. The reason for this conviction is because the wealth and corporate assets contains those that comes from corruption so it is worth to prosecute for substitute money to restore State financial losses. However, not all judges agree with the reasons given above, considering the absence of due process of law in the case of corporate defense. It is interesting to examine the existence and application of the substitute money penalty to corporations in corruption cases and it's benefit for the recovery of the state financial loss? In order to solve the problem, normative legal research methods with legislation and case approach are used. The regulation of substitute money penalty aims to restore the State's financial losses due to corruption. It would be unfair if substitute money penalty imposed to the board while the wealth produce by corruption was actually being accommodated by the corporation. Agreements and guidance are needed to end the polemic among the Corruption Court judges about the possibility of imposing substitute money to the corporation even without it being made as Defendant for the recovery of the state financial loss.
\end{abstract}

Keywords: substitute money, corporation, state financial loss 


\section{A. Pendahuluan}

Korporasi sebagai suatu entitas atau subjek hukum yang keberadaannya memberikan kontribusi yang besar dalam meningkatkan pertumbuhan ekonomi dan pembangunan nasional, namun dalam kenyataannya korporasi ada kalanya juga melakukan pelbagai tindak pidana (corporate crime) yang membawa dampak kerugian terhadap negara dan masyarakat. ${ }^{1}$ Pada kenyataannya juga korporasi digunakan sebagai sarana mengumpulkan dan menyelamatkan aset hasil tindak pidana khususnya tindak pidana korupsi dari para pengurusnya atau orang-orang dari kalangan Penyelenggara Negarayang turut mendesainnya. Sebagaimana perhitungan "ekonomi kriminal" yang memberikan pemahaman bahwa orang berbuat jahat atau melakukan tindak pidana itu sudah memperhitungkan untung dan ruginya. Jika hasil tindak pidana korupsi disimpan dan dilarikan ke dalam (dijadikan) aset korporasi maka penjatuhan pidana penjara terhadap pengurusnya saja tidak akan sebanding dan memadai untuk memulihkan kerugian keuangan Negara.

Padahal diadakannya sistem pemberantasan tindak pidana korupsi, tujuan yang diharapkan adalah kemampuan memenuhi dan mengantisipasi perkembangan kebutuhan hukum masyarakat dalam rangka mencegah dan memberantas secara lebih efektif setiap bentuk tindak pidana korupsi yang sangat merugikan keuangan negara atau perekonomian negara pada khususnya serta masyarakat pada umumnya. Keuangan negara yang dimaksud adalah seluruh kekayaan negara dalam bentuk apapun, yang dipisahkan atau yang tidak dipisahkan, termasuk di dalamnya segala bagian kekayaan negara dan segala hak dan kewajiban yang timbul karena: (a) berada dalam penguasaan, pengurusan, dan pertanggungjawaban pejabat lembaga Negara, baik di tingkat pusat maupun di daerah; (b) berada dalam penguasaan, pengurusan, dan pertanggungjawaban Badan Usaha MilikNegara/ Badan Usaha Milik Daerah, yayasan, badan hukum, dan perusahaan yang menyertakan modal negara, atau perusahaan yang menyertakan modal pihak ketiga berdasarkan perjanjian dengan Negara. Sedangkan yang dimaksud dengan Perekonomian Negara adalah kehidupan perekonomian yang disusun sebagai usaha bersama berdasarkan asas kekeluargaan ataupun usaha masyarakat secara mandiri yang didasarkan pada kebijakan Pemerintah, baik di tingkat pusat maupun di daerah sesuai dengan ketentuan peraturan perundang-undangan yang berlaku yang bertujuan memberikan manfaat, kemakmuran, dan kesejahteraan kepada seluruh kehidupan rakyat.

Hanya melalui penelusuran dan pengejaran aset serta penjeratan pidana terhadap korporasi, kerugian keuangan Negara yang berupa aset korporasi tersebut dapat dipaksakan untuk dikembalikan. $^{2}$

Untuk menutupi (unsur) kerugian Negara itulah diperlukan upaya paksa (dwang middelen). Tindakan atau upaya paksa penegak hukum dalam rangka menyelamatkan uang Negara itu dapat dilakukan secara bertahap, 
yaitu: Pertama, pada tahap pra ajudikasi berupa tindakan atau upaya paksa penegak hukum dengan cara melakukan penyitaan terhadap harta atau benda yang ada pada penguasaan tersangka/terdakwa maupun harta atau benda yang diduga memiliki keterkaitannya dengan suatu tindak pidana, jadi, tidak memiliki sifat limitatif terhadap eksistensi status harta benda tersebut. Isu penyitaan dalam Hukum Acara Pidana sungguh dapat dihubungkan dengan perampasan yang dalam hukum pidana materieel merupakan jenis hukuman, jenis hukuman tambahan. Pada Pasal 38 Kitab Undang-Undang Hukum Acara Pidana (KUHAP) hingga Pasal 46 KUHAP menyinggung penyitaan sebagai salah satu upaya paksa (dwangmiddel atau coercial force) dari kewenangan Penyidik, maka Pasal 128 KUHAP hingga Pasal 130 KUHAP mengatur yang harus ditempuh dalam suatu proses, apa yang dilakukan Penyidik dalam melakukan penyitaan. ${ }^{3}$

Kedua, saat dan pasca ajudikasi, berupa tindakan atau upaya paksa penegak hukum untuk melaksanakan realisasi Uang Pengganti. Namun demikian, undang-undang lama (Undang-Undang Nomor 3 Tahun 1971 tentang Pemberantasan Tindak Pidana Korupsi) tidak mengatur alternatif penyitaan terhadap harta benda terdakwa/terpidana apabila Pelaku tidak melakukan pembayaran Uang Pengganti karena di dalam Penjelasan Pasal 34 hanya dikatakan bahwa akan berlaku tentang pidana denda dalam hal tidak ada realisasi Uang Pengganti. Hal ini berlainan dengan perubahan melalui Undang-Undang Nomor 31 Tahun 1999 tentang Pemberantasan Tindak Pidana Korupsi (UndangUndang Tipikor). Terhadap tidak adanya pembayaran Uang Pengganti dimana terhadap harta benda Pelaku dapat dilakukan dengan cara penyitaan atas harta atau benda yang ada pada penguasaan Tersangka/Terdakwa maupun harta atau benda yang ada pada pihak ketiga tetapi harta atau benda itu diduga memiliki keterkaitannya dengan suatu tindak pidana. jadi, tidaklah memiliki sifat limitatif terhadap eksistensi status harta benda tersebut. ${ }^{4}$

Korporasi sebagai subjek hukum tindak pidana korupsi ditetapkan oleh Pasal 1 angka 3 Undang-Undang Nomor31Tahun1999(termasuk "setiap orang") sehingga konsekuensinya korporasi dapat dituntut pertanggungjawaban dan dapat dijatuhkan pidana. Dalam hal tindak pidana korupsi dilakukan oleh atau atas nama suatu korporasi, maka tuntutan dan penjatuhan pidana dapat dilakukan terhadap korporasi dan atau pengurusnya. ${ }^{5}$ Pidana pokok yang dapat dijatuhkan terhadap korporasi hanya pidana denda, dengan ketentuan maksimum pidana ditambah $1 / 3$ (satu pertiga). ${ }^{6}$ Selain itu korporasi juga dapat dikenakan pidana tambahan yaitu: ${ }^{7}$

a. Perampasan barang bergerak yang berwujud atau yang tidak berwujud atau barang tidak bergerak yang digunakan untuk atau yang diperoleh dari tindak pidana korupsi,

Indriyanto Seno Adji, Korupsi dan Penegakan Hukum, (Jakarta: Diadit Media, 2009), hlm. 255.

Ibid, hlm. 256.

Pasal 20 ayat (1) Undang-Undang Nomor 31 Tahun 1999 Jo. Undang-Undang Nomor 20 Tahun 2001 tentang Pemberantasan Tindak Pidana Korupsi.

$6 \quad$ Pasal 20 ayat (7) Undang-Undang Nomor 31 Tahun 1999 Jo. Undang-Undang Nomor 20 Tahun 2001 tentang Pemberantasan Tindak Pidana Korupsi.

$7 \quad$ Pasal 18 ayat (1) Undang-Undang Nomor 31 Tahun 1999 Jo. Undang-Undang Nomor 20 Tahun 2001 tentang Pemberantasan Tindak Pidana Korupsi. 
termasuk perusahaan milik terpidana di mana tindak pidana korupsi dilakukan, begitu pula dari barang yang menggantikan barang-barang tersebut;

b. Pembayaran uang pengganti yang jumlahnya sebanyak-banyaknya sama dengan harta benda yang diperoleh dari tindak pidana korupsi;

c. Penutupan seluruh atau sebagian perusahaan untuk waktu paling lama 1 (satu) tahun;

d. Pencabutan seluruh atau sebagian hakhak tertentu atau penghapusan seluruh atau sebagian keuntungan tertentu, yang telah atau dapat diberikan oleh Pemerintah kepada terpidana.

Jika terpidana (korporasi) tidak membayar uang pengganti paling lama dalam waktu 1 (satu) bulan sesudah putusan pengadilan yang telah memperoleh kekuatan hukum tetap, maka harta bendanya dapat disita oleh Jaksa dan dilelang untuk menutupi uang pengganti tersebut. ${ }^{8}$ Pelaksanaan lelang dilakukan selambat-lambatnya 3 (tiga) bulan setelah dilakukan penyitaan. ${ }^{9}$ Selain itu dapat juga dipertimbangan penghukuman oleh hakim bahwa bilamana tidak juga dianggap cukup menjerakan melalui pengenaan pidana pembayaran uang pengganti maka bisa dijatuhkan pula pidana tambahan berupa penutupan usaha korporasi selamanya ataupun dalam waktu yang sementara. Bagi korporasi, memilih membayar pidana tambahan uang pengganti lebih realistis daripada aset-asetnya disita dan dilelang atau bahkan berujung pada akibat krusial yaitu harus gulung tikar atas tidak terpenuhinya tangung jawab hukum.

Pada praktiknya, belum terdapat kesamaan pandangan mengenai parameter penentuan besaran uang pengganti dimana dalam beberapa kondisi sering dihitung berdasarkan jumlah kerugian Negara yang ditimbulkan, namun pada kondisi lain dihitung berdasarkan jumlah harta benda yang diperoleh dari tindak pidana korupsi tersebut. Untuk menjawab permasalahan tersebut, diperlukan adanya suatu pengaturan yang jelas mengenai parameter perhitungan besaran uang pengganti. Sesuai dengan Pasal 18 ayat (1) Undang-Undang Nomor 31 Tahun 1999 yang pada intinya mengatakan bahwa besaran jumlah uang pengganti didasarkan dari besaran harta benda terpidana yang diperoleh dari tindak pidana korupsi. Oleh karenanya Mahkamah Agung melalui Peraturan Mahkamah Agung Nomor 5 Tahun 2014 tentang Pidana Tambahan Uang Pengganti dalam Tindak Pidana Korupsi menegaskan bahwa parameter perhitungan besaran uang pengganti adalah sebanyak-banyaknya sama dengan harta benda yang diperoleh dari tindak pidana korupsi. Dengan demikian, pemahaman bahwa parameter perhitungan besaran uang pengganti ditinjau dari besaran kerugian Negara sudah tidak dapat diterapkan dalam suatu persidangan tindak pidana korupsi. ${ }^{10}$

Selain masalah besaran uang pengganti, persoalan lain yang juga menimbulkan polemik 
adalah berkaitan dengan dijatuhinya pidana uang pengganti kepada korporasi yang tidak dijadikan Terdakwa. Dalam Pasal 17 Undang-Undang Nomor 31 Tahun 1999 dinyatakan bahwa selain dijatuhi pidana pokok, Terdakwa dapat dijatuhi pidana tambahan sebagaimana dimaksud dalam Pasal 18. Berdasarkan ketentuan tersebut maka pidana tambahan berupa pembayaran uang pengganti hanya dapat dijatuhkan kepada Terdakwa. Namun dalam perkembangannya tak jarang Jaksa Penuntut Umum memasukkan tuntutan pembayaran uang pengganti juga kepada pihak ketiga (dalam hal ini termasuk korporasi). Tuntutan yang demikian selain tidak memiliki dasar hukum, pada prinsipnya juga melanggar prinsip-prinsip peradilan yang fair (fair trial), oleh karena pihak ketiga tersebut dikenakan tuntutan tanpa pernah diberikan kesempatan untuk melakukan pembelaan diri layaknya Terdakwa dalam persidangan yang terbuka untuk umum. ${ }^{11}$

Pada praktiknya, Mahkamah Agung melakukan terobosan hukum yaitu dengan mengabulkan tuntutan Jaksa Penuntut Umum agar korporasi yang tidak dijadikan Terdakwa dituntut pemidanaan berupa pembayaran uang pengganti. Sebagaimana dalam perkara PT. Indosat Mega Media (PT.IM2), PT. Adhi Karya (PT.AK), PT. Nindya Karya (PT.NK), PT. Sumigita Jaya (PT.SJ), dan PT. Green Planet Indonesia (PT.GPI). Keempat korporasi tersebut, tanpa dijadikan Terdakwa tetapi harus menanggung pidana tambahan berupa pembayaran uang pengganti atas perkara Pengurusnya yang notabene adalah Terdakwanya. Pertimbangan hukum Mahkamah Agung (Putusan Nomor787 K/Pid.Sus/2014) dalam menjatuhkan pidana uang pengganti terhadap korporasi yang tidak dijadikan sebagai Terdakwa tersebut adalah bahwa pertanggungjawaban menurut Pasal 20 ayat (1) Undang-Undang Nomor 31 Tahun 1999 Jo. Undang-Undang Nomor 20 Tahun 2001 tentang Pemberantasan Tindak Pidana Korupsi ini dilakukan oleh korporasi dan/atau pengurusnya. Oleh karenanya meskipun Jaksa Penuntut Umum tidak melakukan penuntutan secara khusus terhadap korporasi (PT Indosat Mega Media), namun peran Terdakwa dalam surat dakwaan adalah dalam kapasitas sebagai Direktur Utama sehingga pidana tambahan berupa uang pengganti dapat dijatuhkan kepada PT Indosat Mega Media.

Problematika penerapan pidana uang pengganti terhadap korporasi dalam perkara korupsi ini sampai sekarang belum dapat terselesaikan. Para hakim memiliki interpretasi yang berbeda dimana di satu pihak menganggap adanya pelanggaran hak asasi manusia dan pelanggaran terhadap asas fair trial, sedangkan di pihak lain secara tegas menyatakan bahwa usahanya menjatuhkan pidana uang pengganti tersebut adalah dalam rangka memulihkan kerugian keuangan Negara karena bilamana hanya mengandalkan pemidanaan terhadap pengurusnya yang notabene hasil tindak pidana korupsi tersebut telah menjadi harta atau aset korporasi maka tidaklah adil pengurusnya yang menanggung pembayaran uang pengganti tersebut. Berdasarkan polemik ini maka dapat ditarik beberapa permasalahan yang relevan untuk diteliti dan dibahas yaitu: Bagaimanakah kedudukan pidana uang pengganti terhadap korporasi dalam perkara tindak pidana korupsi menurut hukum positif? kemudian

11 Penjelasan Pasal 3 Peraturan Mahkamah Agung Nomor 5 Tahun 2014 tentang Pidana Tambahan Uang Pengganti Dalam Tindak Pidana Korupsi. 
bagaimanakah eksistensi pidana uang pengganti kepada korporasi dalam perkara korupsi? Dan bagaimanakah implikasi penerapan pidana uang pengganti terhadap korporasi dalam perkara korupsi bagi upaya pemulihan kerugian keuangan Negara?

\section{B. Metode Penelitian}

Penelitian ini menggunakan metode normatif. Terdapat 3 (tiga) pendekatan untuk mengkaji ketiga permasalahan yang coba dibahas dengan metode penelitian normatif ini yaitu pendekatan perundang-undangan (statute approach), pendekatan kasus (case approach) serta pendekatan konseptual (conseptual approach). Pendekatan perundangundangan diperlukan dalam rangka menelusuri ratio legis dan dasar ontologis lahirnya peraturan perundang-undangan. ${ }^{12}$ Pendekatan kasus digunakan untuk menemukan the ratio decidendi atau reasoning, yaitu pertimbangan pengadilan untuk sampai pada suatu putusan ${ }^{13}$ dimana letak terobosan hukum yang bertujuan memberi akses keadilan. $^{14}$ Pendekatan konseptual digunakan untuk memahami secara presisi dan akurat berbagai konsep yang digunakan oleh prinsip hukum dalam undangundang maupun doktrin para ahli hukum. ${ }^{15}$

Sumber data yang digunakan dalam penelitian adalah data sekunder yang terdiri atas bahan hukum primer berupa peraturan perundang-undangan, konvensi hukum internasional dan putusan pengadilan serta bahan hukum sekunder berupa literatur dan hasil penelitian. Peraturan perundang-undangan yang digunakan antara lain Kitab UndangUndang Hukum Pidana (KUHP), UndangUndang Nomor 31 Tahun 1999 sebagaimana diubah oleh Undang-Undang Nomor 20 Tahun 2001 tentang Pemberantasan Tindak Pidana Korupsi, Peraturan Mahkamah Agung Nomor 13 Tahun 2016 tentang Tata Cara Penanganan Perkara Tindak Pidana Oleh Korporasi, Peraturan Mahkamah Agung Nomor 5 Tahun 2014 tentang Pidana Tambahan Uang Pengganti Dalam Tindak Pidana Korupsi, Peraturan Jaksa Agung Republik Indonesia Nomor: Per-028/A/ $\mathrm{JA} / 10 / 2014$ tentang Pedoman Penanganan Perkara Pidana Dengan Subjek Hukum Korporasi, Peraturan Jaksa Agung Nomor: Per013/A/JA/06/2014 tentang Pemulihan Aset, dan Surat Edaran Kejaksaan Agung RI Nomor B-036/A/Ft.1/06/2009 perihal Korporasi Sebagai Tersangka/Terdakwa DalamTindak Pidana Korupsi dan Konvensi internasional terkait pertanggungjawaban korporasi dalam tindak pidana korupsi, yaitu United Nation Covention Against Corruption (UNCAC) 2003. Putusan pengadilan yang dikaji terkait dengan putusan pemidanaan korporasi pelaku tindak pidana korupsi diantaranya yaitu Putusan Pengadilan Negeri Jakarta Pusat Nomor 234/ PID.B/2011/PN.JKT.PST, Putusan Pengadilan Tinggi Jakarta Nomor 241/PID/2012/PT.DKI, dan Putusan Mahkamah Agung Nomor 2239 K/ PID.SUS/2012.

Adapun literatur yang digunakan dalam kajian agar terhindar dari kekeliruan pandangan

Peter Mahmud Marzuki, Penelitian Hukum (Jakarta: Kencana, 2014), hlm. 93-94.

Ibid, hlm. 64.

14 Sulistyowati Irianto dan Lim Sing Meij, Praktik Penegakan Hukum: Arena Penelitian Sosiolegal Yang Kaya. Dalam Sulistyowati Irianto dan Shidarta. Metode Penelitian Hukum (Konstelasi dan Refleksi) (Jakarta: Yayasan Pustaka Obor Indonesia. 2011), hlm. 191.

15 Peter Mahmud Marzuki, Loc Cit, hlm. 178. 
adalah yang berkaitan dengan konsep uang pengganti, filsafat pemidanaan tindak pidana korupsi dan teori pertanggungjawaban pidana korporasi. Bahan-bahan hukum dan literatur tersebut dikumpulkan melalui metode sistematis dan dicatat dalam kartu antara lain permasalahannya, asas-asas, argumentasi, implementasi yang ditempuh, alternatif pemecahannya dan lain sebagainya. Data yang telah dikumpulkan kemudian dideskripsikan dan diinterpretasikan sesuai pokok permasalahan selanjutnya disistematisasi, dieksplanasi, dan diberikan argumentasi. Metode analisis yang diterapkan untuk mendapatkan kesimpulan atas permasalahan yang dibahas adalah melalui analisis yuridis kualitatif.

\section{Pembahasan}

\section{Kedudukan Pidana Uang Pengganti terhadap Korporasi dalam Perkara Tindak Pidana Korupsi Menurut Hukum Positif}

Pengertian korporasi, erat kaitannya dengan bidang hukum perdata. sebab pengertian korporasi merupakan terminologi yang erat dengan istilah badan hukum (rechts persoon), dan badan hukum itu sendiri merupakan terminologi yang erat kaitannya dengan bidang hukum perdata. Menurut Subekti dan Tjitrosudibio, korporasi adalah suatu perseroan yang merupakan badan hukum. ${ }^{16}$ Sedangkan
Rudhi Prasetyo, menyatakan bahwa kata korporasi sebutan yang lazim dipergunakan di kalangan pakar hukum pidana untuk menyebut apa yang biasa dalam bidang hukum lain khususnya bidang hukum perdata, sebagai badan hukum atau dalam bahasa Belanda disebut sebagai rechts person, atau yang dalam bahasa Inggris disebut sebagai legal entities atau corporation. ${ }^{17}$ Sementara itu menurut Sutan Remi Sjahdeini bahwa dalam hukum pidana, korporasi meliputi baik badan hukum maupun bukan badan hukum. Bukan saja badan-badan hukum seperti perseroan terbatas, yayasan, koperasi atau perkumpulan yang telah disahkan sebagai badan hukum yang digolongkan sebagai korporasi menurut hukum pidana, tetapi juga firma, persekutuan komanditer atau CV dan persekutuan atau matschap, yaitu badan-badan usaha yang menurut hukum perdata bukan suatu badan hukum. ${ }^{18}$

Korporasi telah diakui sebagai subjek yang lahir oleh hukum dan dapat bertindak dalam lalu lintas hukum serta dapat dimintai pertanggungjawaban pidana ${ }^{19}$ termasuk dalam perkara korupsi, korporasi mendapatkan penegasan pengaturan sebagai subjek hukum "orang". ${ }^{20}$ Demikian halnya dengan pertanggungjawaban dan sistem pemidanaannya diatur secara rinci yaitu dalam hal tindak pidana korupsi dilakukan oleh atau atas nama suatu korporasi, maka tuntutan dan

16 Subekti dan R. Tjitrosudibio, Kamus Hukum, (Jakarta: Paramita, 1979), Hlm.34.

17 Rudi Prasetyo, Perkembangan Korporasi dalam Proses Modernisasi dan Penyimpangan-Penyimpangannya, Makalah disampaikan pada Seminar Nasional kejahatan Korporasi di FH UNDIP, (Semarang, 23-24 November, 1989), Hlm. 2..

18 Sutan Remi Sjahdeini, Pertanggungjawaban Pidana Korporasi, (Jakarta: Grafiti Pers, 2006), Hlm. 43

19 Faizal Adi Surya. "Tinjauan Mediasi Penal Dalam Perspektif Hukum Adat dan Hukum Islam". Jurnal Jurisprudence, Volume 5 Nomor 2 September (2015), hlm. 44.

20 Pasal 1 angka 3 Undang-Undang Nomor 31 Tahun 1999 Jo. Undang-Undang Nomor 20 Tahun 2001 tentang Pemberantasan Tindak Pidana Korupsi. 
penjatuhan pidana dapat dilakukan terhadap korporasi dan atau pengurusnya. ${ }^{21}$ Artinya secara komulatif-alternatif dapat dituntut dan diputus pemidanaannya bilamana dilakukan oleh atau atas nama suatu korporasi sehingga dapat dilakukan terhadap "korporasi dan pengurus" atau terhadap "korporasi" saja atau "pengurus" saja. Selanjutnya untuk mengidentifikasi bahwa tindak pidana korupsi dilakukan oleh korporasi adalah apabila tindak pidana tersebut dilakukan oleh orang-orang baik berdasarkan hubungan kerja maupun berdasarkan hubungan lain, bertindak dalam lingkungan korporasi tersebut baik sendiri maupun bersama-sama. ${ }^{22}$

Jika diteliti dengan seksama, formulasi aturan pemidanaan (pertanggungjawaban pidana) korporasi dalam tindak pidana korupsi yang sudah diatur oleh Undang-Undang tentang Pemberantasan Tindak Pidana korupsi masih memiliki kelemahan-kelemahan. ${ }^{23}$ oleh karena itu selain diatur dalam Undang-Undang Tipikor, hukum acara pidana korporasi baik dalam tahap penyidikan, penuntutan, persidangan, hingga eksekusi putusan diatur oleh beberapa peraturan di bawah undang-undang yaitu diantaranya Surat Edaran Kejaksaan Agung RI Nomor
B-36/A/Ft.1/06/2009 perihal Korporasi Sebagai Tersangka/Terdakwa Dalam Tindak Pidana Korupsi dan Peraturan Jaksa Agung Republik Indonesia Nomor: Per-028/A/JA/10/2014 tentang Pedoman Penanganan Perkara Pidana Dengan Subjek Hukum Korporasi, dan Peraturan Mahkamah Agung Nomor 13 Tahun 2016 tentang Tata Cara Penanganan Perkara Tindak Pidana oleh Korporasi. Keberadaan ketiga peraturan tersebut adalah berfungsi sebagai pengisi kekosongan hukum daripada kelemahan teknis acara penanganan tindak pidana korporasi ${ }^{24}$ dalam Undang-Undang Tipikor.

Kelemahan Undang-Undang Tipikor, ternyata tidak hanya sebatas ketentuan teknis acara penanganan tindak pidana korporasi, tetapi juga terkait dengan ketentuan pidana tambahan berupa pembayaran uang pengganti khususnya yang diatur dalam ketentuan Pasal 18 UndangUndang Nomor 31 Tahun 1999 meninggalkan beberapa permasalahan dalam praktik. ${ }^{25}$ Secara eksplisit Pasal 18 tersebut mengatur bahwa:

1) Selain pidana tambahan sebagaimana dimaksud dalam Kitab Undang-Undang Hukum Pidana, sebagai pidana tambahan adalah:

$21 \quad$ Pasal 20 ayat (1) Undang-Undang Nomor 31 Tahun 1999 Jo. Undang-Undang Nomor 20 Tahun 2001 tentang Pemberantasan Tindak Pidana Korupsi.

22 Pasal 20 ayat (2) Undang-Undang Nomor 31 Tahun 1999 Jo. Undang-Undang Nomor 20 Tahun 2001 tentang Pemberantasan Tindak Pidana Korupsi.

23 Kelemahan-kelemahan itu diantaranya: Pertama, masalah kapan korporasi melakukan tindak pidana korupsi, sudah diatur tetapi masih belum jelas mengenai pengertian hubungan kerja dan hubungan lainnya sehingga dapat menimbulkan kesimpangsiuran penafsiran yangdapat menjadi salah satu masalah pada saataplikasi; Kedua, masalah tindak pidana korupsiyang dilakukan oleh korporasi, khususnya mengenai pemufakatan jahat; dan Ketiga, masalah sanksi pidana terhadap korporasi antara lain: masalah perumusan pemberatan sanksi pidana pada pasal 2 ayat (2), masalah kapan dikatakan terjadinya pengulangan tindak pidana korupsi, dan masalah perumusan sanksi pidana pokok terhadap korporasi dalam pasal 20 ayat (7). Lihat dalam Orpa Ganefo Manuain, Pertanggungjawaban Pidana Korporasi dalam Tindak Pidana Korupsi, Tesis, (Semarang: Magister Hukum Universitas Diponegoro, 2005), hlm. 110-11.

24 Budi Suhariyanto, Pertanggungjawaban Pidana Korporasi Berdasarkan Corporate Culture Model dan Implikasinya Bagi Kesejahteraan Masyarakat, Jurnal Rectsvinding Volume 6 Nomor 3 (Desember 2017), hlm. 448.

25 Natangsa Surbakti, Peradilan Restoratif: Dalam Bingkai Empiris, Teori dan Kebijakan. (Yogyakarta: Genta Publishing, 2015), hlm. 204-205. 
a. Perampasan barang bergerak yang berwujud atau yang tidak berwujud atau barang tidak bergerak yang digunakan untuk atau yang diperoleh dari tindak pidana korupsi, termasuk perusahaan milik terpidana dimana tindak pidana korupsi dilakukan, begitu pula dari barang yang menggantikan barang-barang tersebut;

b. Pembayaran uang pengganti yang jumlahnya sebanyak-banyaknya sama dengan harta benda yang diperoleh dari tindak pidana korupsi;

c. Penutupan seluruh atau sebagian perusahaan untuk waktu paling lama 1 (satu) tahun;

d. Pencabutan seluruh atau sebagian hakhak tertentu atau penghapusan seluruh atau sebagian keuntungan tertentu, yang telah atau dapat diberikan oleh Pemerintah kepada terpidana.

2) Jika terpidana tidak membayar uang pengganti sebagaimana dimaksud dalam ayat (1) huruf b paling lama dalam waktu 1 (satu) bulan sesudah putusan pengadilan yang telah memperoleh kekuatan hukum tetap, maka harta bendanya dapat disita oleh jaksa dan dilelang untuk menutupi uang pengganti tersebut.

3) Dalam hal terpidana tidak mempunyai harta benda yang mencukupi untuk membayar uang pengganti sebagaimana dimaksud dalam ayat (1) huruf b, maka dipidana denganpidana penjara yang lamanya tidak melebihi ancaman maksimum dari pidana pokoknya sesuai dengan ketentuan dalam undang-undang ini dan lamanya pidana

tersebut sudah ditentukan dalam putusan pengadilan.

Undang-Undang Tipikor tidak memberikan acuan dalam merumuskan pidana penjara pengganti dalam hal uang pengganti tidak dibayar dalam jangka waktu tertentu telah menimbulkan banyak disparitas dalam penjatuhan lamanya pidana penjara pengganti. Misalnya pidana penjara pengganti selama 12 (dua belas) bulan dijatuhkan oleh Putusan Nomor 655 K/Pid.Sus/2010 sebagai pengganti jika tidak membayar uang sejumlah Rp.378.116.230.813,. Hal ini sangat timpang dengan Putusan Nomor $50 \mathrm{~K} /$ Pid.Sus/2010 yang juga menetapkan pidana penjara pengganti selama 12 (dua belas) bulan atas tidak terbayarkannya uang pengganti sejumlah Rp. 2.800.000,-. Disparitas ini memperlihatkan bahwa penjatuhan uang pengganti dalam jumlah besar tidak serta merta diikuti dengan pidana penjara pengganti dalam waktu yang sepadan dengan nilai uang pengganti, begitu pula sebaliknya. Jika uang pengganti yang dijatuhkan cukup besar namun penjara pengganti yang ditetapkan tidak terlalu besar maka terdapat celah permainan antara jaksa eksekutor dengan terpidana untuk berkolusi agar harta hasil korupsi tidak dieksekusi namun langsung dikonversi menjadi pidana pengganti. Hal ini mengingat dalam perkara yang pidana penjara penggantinya tidak sepadan dengan nilai uang pengganti, akan lebih ekonomis untuk terpidana jika ia menjalani pidana penjara pengganti tersebut dibanding membayar uang pengganti. ${ }^{26}$

26 Nur Syarifah, Mengupas Permasalahan Pidana Tambahan Pembayaran Uang Pengganti dalam Perkara Korupsi, diakses dari www.leip.or.id pada tanggal 10 November 2017. 
Untuk menjawab permasalahan tersebut maka Mahkamah Agung menerbitkan Perma Nomor 5 Tahun 2014. Dalam Peraturan Mahkamah Agung ini, parameter perhitungan besaran uang pengganti ialah sebanyakbanyaknya sama dengan harta benda yang diperoleh dari tindak pidana korupsi. Berkaitan dengan hal ini maka para hakim pada tingkat judex facti diharuskan dapat menggali keterangan mengenai besarnya jumlah harta benda yang diperoleh Terdakwa dari suatu tindak pidana korupsi. Dengan demikian apabila terjadi tindak pidana korupsi secara bersamsama, maka hakim dapat menjatuhkan besaran uang pengganti didasarkan harta benda yang diperoleh masing-masing Terdakwa. Selain itu sehubungan Undang-Undang Tipikor tidak mengatur perhitungan lama penjara pengganti yang harus dijalani Terpidana apabila sudah membayarkan sebagian uang pengganti kepada Negara. Hal ini menimbulkan suatu ketidak-adilan bagi Terpidana, yang sudah membayarkan sebagian uang pengganti, akan tetapi tetap harus menjalani penjara pengganti layaknya sama sekali tidak membayar uang pengganti. Dalam hal ini pembayaran uang pengganti tersebut akan diperhitungkan secara proporsional sebagai pengurangan lama penjara pengganti yang harus dijalani Terdakwa.

Jika subjek hukum yang didakwa dalam perkara korupsi adalah korporasi maka menurut Perma Nomor 5 Tahun 2014 ini mengatur bahwa pidana penjara pengganti sebagai ganti dari tidak dibayarkannya uang pengganti adalah tidak dapat diterapkan (Pasal 7). Optimalisasi pelunasan uang pengganti terhadap korporasi ini dapat dilakukan dengan menyita dan melelang aset milik korporasi tersebut. jika aset-aset tersebut telah habis sementara itu masih terdapat kekurangan kewajiban uang pengganti yang harus dibayarkan, Jaksa dapat mengajukan korporasi tersebut untuk pailit (Penjelasan Pasal 7 ayat (2)). Hal lain yang berkaitan dengan korporasi dalam hal pelaksanaan ketentuan uang pengganti yaitu apabila pengadilan mendapatkan perkara dimana dalam surat tuntutannya Jaksa Penuntut Umum memasukkan tuntutan agar terdapat pihak ketiga (termasuk korporasi) yang dituntut pembayaran uang pengganti, maka pengadilan harus menolak tuntutan tersebut dan menyarankan agar Jaksa Penuntut Umum mendakwa pihak ketiga terlebih dahulu dalam perkara tersendiri. Selain itu apabila pengadilan mengabulkan tuntutan Jaksa Penuntut Umum tersebut maka akan timbul permasalahan hukum dalam eksekusinya (Penjelasan Pasal 6).

\section{Eksistensi Pidana Uang Pengganti Kepada Korporasi dalam Perkara Korupsi}

Meskipun telah ditegaskan secara normatif bahwa korporasi adalah salah satu subjek hukum dan dapat dipertanggungjawabkan dalam tindak pidana korupsi sejak tahun 1999 (dimana UU Tipikor mulai diberlakukan), namun sampai dengan tahun 2018 (sekitar 19 tahunan) sangat sedikit perkara korupsi dimana korporasi dijadikan sebagai terdakwa dan dituntut serta dipidana. ${ }^{27}$ Realitasnya proses pemidanaan banyak yang berhenti pada pengurusnya saja dan tidak ada tindak

Budi Suhariyanto, Progresivitas Putusan Pemidanaan terhadap Korporasi Pelaku Tindak Pidana Korupsi, Jurnal De Jure Volume 16 Nomor 2, (Juni 2016) hlm. 207. 
lanjut untuk menjerat dan melakukan proses pemidanaan terhadap korporasinya. ${ }^{28}$ Padahal tidak sedikit perkara korupsi yang diinisiasi oleh pengurus korporasi yang melakukan kegiatan koruptif merugikan keuangan negara untuk dan atas nama serta demi keuntungan korporasinya. Ironisnya penegak hukum tidak sepenuhnya mampu dan berhasil melakukan pemulihan kerugian keuangan negara tersebut disebabkan adanya berbagai modus penghilangan jejak dan penyembunyian aset hasil korupsi yang cukup susah untuk pembuktiannya. ${ }^{29}$

Jika suatu tindak pidana dilakukan atau bahkan hanya diperintahkan oleh pengurus korporasi, seharusnya korporasi itu bisa dijerat. Adapun sanksi pidana yang harus diberikan kepada korporasi tidak cukup hanya pidana denda saja. Korporasi yang melakukan kejahatan, seharusnya dikenai pidana pengembalian aset $^{30}$ hasil tindak pidana korupsi diantaranya berupa penerapan pidana pembayaran uang pengganti. Sejauh ini baru 5 (lima) perkara yang menerapkan pemidanaan berupa pembayaran uang pengganti terhadap korporasi yang terkait dengan perkara tindak pidana korupsi yaitu PT. IM2, PT. HK, PT. NK, PT. AK, PT. SJ dan PT. GPI. Memang selain keempat korporasi tersebut ada perkara PT. Giri Jaladhi Wana dan PT. Cakrawala Nusadimensi yang juga diproses oleh peradilan tindak pidana korupsi dan dipidana secara inkracht, akan tetapi pidana yang ditetapkan terhadap keduanya hanya berkaitan dengan denda dan penutupan usaha sementara serta tidak dijatuhkan pidana tambahan berupa pembayaran uang pengganti.
Berbeda dengan keempat korporasi yang dipidana untuk membayar uang pengganti tanpa yang bersangkutan ditetapkan dan diproses sebagai Terdakwa. Misalnya perkara PT. IM2 dipidana dengan pidana uang pengganti dalam putusan pemidanaan terhadap Direktur Utamanya yang notabene diputus bersalah melakukan tindak pidana korupsi. Hal ini tentu menyimpangi ketentuan yang ditetapkan oleh Peraturan Mahkamah Agung Nomor 5 Tahun 2014 yaitu seharusnya pengadilan menolak tuntutan tersebut dan menyarankan agar Jaksa Penuntut Umum mendakwa pihak ketiga terlebih dahulu dalam perkara tersendiri karena yang menjadi Terdakwa adalah Indar Atmanto selaku Direktur IM2 didakwa Jaksa Penuntut Umum melanggar Pasal 2 ayat (1) jo Pasal 18 ayat (1), (3) Undang-Undang Tipikor Jo. Pasal 55 ayat (1) ke 1 KUHP sebagai dakwaan primair dan subsidernya melanggar Pasal 3 Pasal 18 ayat (1), (3) Undang-Undang Tipikor Jo. Pasal 55 ayat (1) ke 1 KUHP.

Atas dakwaan tersebut di atas, Jaksa mengajukan tuntutan yaitu agar Terdakwa IA dinyatakan bersalah melakukan tindak pidana korupsi sebagaimana dakwaan primair, dan karenanya dijatuhkan pidana penjara 10 (sepuluh) tahun dan denda sebesar Rp. 500.000.000,- serta uang pengganti sebesar Rp.1.358.343.346.674.- dibebankan kepada PT Indosat dan PT Indosat Mega Media yang penuntutannya dilakukan secara terpisah. Majelis hakim Pengadilan Negeri Jakarta Pusat melalui putusannya Nomor 01/Pid.Sus/2013/ PN.Jkt.Pst memutuskan dengan menyatakan

28 Budi Suhariyanto, RestoratifJustice dalam Pemidanaan Korporasi Pelaku Korupsi Demi Optimalisasi Pengembalian Kerugian Negara. Jurnal RechtsvindingVolume 5 Nomor 3, (Desember 2016), hlm.428.

29 ibid. hlm. 422.

30 Henry Donald Toruan, Pertanggungjawaban Pidana Korupsi Korporasi.Jurnal Rechtsvinding Volume 3 Nomor 3,(Desember, 2014). hlm. 398. 
Terdakwa IA terbukti terbukti secara sah dan meyakinkan bersalah melakukan tindak pidana korupsi dilakukan secara bersama-sama dan menjatuhkan pidana terhadap terdakwa dengan pidana penjara selama 4 (empat) tahun dan menjatuhkan pidana denda sebesar Rp. 200.000.000,- dan bila denda tersebut tidak dibayar diganti dengan pidana kurungan selama 3 (tiga) bulan serta menghukum PT Indosat Mega Media membayar uang pengganti sebesar Rp. 1.358.343.346.674 paling lambat 1 (satu) tahun setelah putusan ini mempunyai kekuatan hukum tetap.

Atas putusan Pengadilan Negeri Jakarta Pusat tersebut, Terdakwa IA melakukan upaya hukum banding, majelis hakim Pengadilan Tinggi Jakarta melalui putusannya Nomor 33/ PID/TPK/2013/PT.DKI memutuskan mengubah putusan Pengadilan Negeri sehingga amarnya menyatakan Terdakwa IA terbukti secara sah dan meyakinkan bersalah melakukan Tindak Pidana Korupsi dilakukan secara bersama-sama dan menjatuhkan pidana terhadap Terdakwa tesebut dengan pidana penjara selama 8 (delapan) tahun dan menjatuhkan pidana denda sebesar Rp. 200.000.000,- dan bila denda tersebut tidak dibayar diganti pidana kurungan selama 3 (tiga) bulan. Pengadilan Tinggi Jakarta ini tidak menghukum PT.IM2 untuk membayar uang pengganti sebagaimana putusan Pengadilan Negeri dan tuntutan Jaksa disebabkan dasar pertimbangan yaitu:

Bahwa pidana tambahan ini harus selalu mengikuti pidana pokok, yaitu kepada siapa pidana pokok itu dikenakan. Hal yang tidak wajar atau melanggar hukum apabila pidana pokokya dikenakan pada subyek hukum lain dan pidana tambahan dikenakan pada subyek hukum yang lain atau dalam perkara ini subyek hukum yang lain tersebut tidak didakwakan. Dengan demikian uang pengganti tidak dapat dibebankan kepada PT Indosat Mega Media sebagai korporasi.

Pada tingkat Kasasi, Mahkamah Agung melalui putusannya Nomor 787 K/Pid. Sus/2014 memutuskan memperbaiki amar putusan Pengadilan Tinggi Jakarta Nomor 33/Pid/TPK/2013/PT.DKI yang mengubah Putusan Pengadilan Negeri Jakarta Pusat Nomor 01/Pid.Sus/TPK/2013/PN.Jkt.PST tanggal 8 Juli 2013 sekedar mengenai pidana denda dan uang pengganti sehingga amarnya menyatakan Terdakwa IA terbukti secara sah dan meyakinkan bersalah melakukan tindak Pidana Korupsi Dilakukan Secara Bersamasama dan menjatuhkan pidana terhadap Terdakwa tersebut dengan Pidana Penjara selama 8 (delapan) tahun dan menjatuhkan Pidana Denda sebesar Rp. 300.000.000,- dan bila denda tersebut tidak dibayar diganti pidana kurungan selama 6 (enam) bulan serta menghukum PT.IM2 membayar uang pengganti sebesar Rp. 1.358.343.346.674,- dengan ketentuan apabila PT.IM2 tidak membayar uang pengganti tersebut paling lambat 1 (satu) bulan sesudah putusan mempunyai kekuatan hukum tetap maka harta benda PT.IM2 disita oleh Jaksa dan dilelang untuk membayar uang pengganti tersebut. Putusan pemidanaan dengan pidana tambahan berupa kewajiban atau pembebanan pembayaran uang pengganti terhadap PT.IM2 tersebut didasarkan atas pertimbangan majelis hakim Kasasi yaitu:

Bahwa pertanggungjawaban menurut Pasal 20 ayat (1) Undang-Undang Nomor 31 Tahun 1999 jo Undang-Undang Nomor 20 Tahun 2001 tentang Pemberantasan Tindak Pidana Korupsi ini dilakukan oleh korporasi dan/atau pengurusnya. Oleh karenanya meskipun Jaksa Penuntut Umum tidak melakukan penuntutan secara khusus terhadap korporasi (PT Indosat Mega Media), namun peran Terdakwa dalam surat 
dakwaan adalah dalam kapasitas sebagai Direktur Utama sehingga pidana tambahan berupa uang pengganti dapat dijatuhkan kepada PT Indosat Mega Media. Oleh karena itu Mahkamah Agung memandang perlu memperbaiki amar putusan Pengadilan Tinggi dengan menjatuhkan uang pengganti kepada korporasi.

Putusan Mahkamah Agung lainnya yang senada dengan putusan IM2 diatas dimana korporasi dapat dipidana dengan pidana uang pengganti meskipun tidak dijadikan Terdakwa adalah putusan nomor 1577 K/Pid.Sus/2016 (a/n 2428 K/Pid.Sus/2014 (a/n Wijaya Imam Santosa, mantan Kepala Divisi VII PT Adhi Karya), Mahkamah Agung (MA) melakukan terobosan hukum dengan memvonis korporasi konstruksi pelat merah, PT Adhi Karya, membayar uang pengganti sebesar Rp3,3 miliar. Putusan itu disebut sebagai terobosan hukum karena Adhi Karya tidak masuk dakwaan mantan Kepala Divisi VII PT Adhi Karya, Wijaya Imam Santosa. Adapun pertimbangan Mahkamah Agung menyatakan bahwa BUMN itu ikut bertanggung jawab dalam korupsi proyek konstruksi jaringan air minum di empat kecamatan di Kabupaten Karangasem, Bali. Kerugian Negara sebesar Rp3,3 miliar tersebut lebih tepat dibebankan kepada PT. Adhi Karya (Persero) Tbk. walaupun PT. Adhi Karya (Persero) Tbk. tidak turut dijadikan Terdakwa oleh Penuntut Umum, karena Terdakwa bertindak melaksanakan Surat Perjanjian Kerja untuk dan atas nama PT. Adhi Karya (Persero) Tbk. dan seluruhnya kerugian
Negara tersebut masuk ke rekening PT. Adhi Karya (Persero) Tbk. ${ }^{31}$

\section{Implikasi Penerapan Pidana Uang Pengganti terhadap Korporasi dalam Perkara Korupsi bagi Upaya Pemulihan Kerugian Keuangan Negara}

Terhadap persoalan apakah suatu korporasi dapat dijatuhi sanksi pidana berupa pembayaran uang pengganti tanpa diajukan sebagai Terdakwa, dalam praktek terdapat dua aliran yaitu: ${ }^{32}$

1. Aliran pertama, penjatuhan sanksi pidana terhadap suatu korporasi dapat dilakukan, meskipun tidak diajukan sebagai terdakwa dalam suatu perkara, adapun argumentasinya adalah apabila tindak pidana korupsi dilakukan oleh pengurus dalam kedudukannya sebagai Direktur Utama (Directing Mind) suatukorporasi yaitu: Pertama, apabila tindak pidana korupsi itu menguntungkan korporasi; Kedua, tindak pidana korupsi merupakan extra ordinary crime sehingga penangannya harus secara extrapula; Ketiga, mengingat salah satu tujuan dari Undang-Undang Tindak Pidana Korupsi adalah pemulihan aset negara/asset recovey, sehingga untuk mencapai tujuan tersebut, penanganan terhadap pelaku Tindak Pidana Korupsi sebaiknya dilakukan dengan sederhana, murah dan cepat.

2. Aliran kedua, penjatuhan pidana kepada seseorang harus didasarkan kepada

31 Artidjo Alkostar, Kedudukan dan Tanggung Jawab Pidana Korporasi dalam Tindak Pidana Korupsi, Disampaikan dalam seminar tentang "Kedudukan dan tanggung jawab korporasi dalam tindakpidana korupsi" Mahkamah Agung Badiklat Hukum dan Peradilan, Selasa tanggal 15 Nopember 2016, di Hotel Grand Mercure Jakarta Pusat. hlm. 47.

32 Biro Hukum dan Humas Badan Urusan Administrasi Mahkamah Agung. 2015. Kompilasi Penerapan Hukum Oleh Hakim dan Strategi Pemberantasan Korupsi. (Jakarta: Biro Hukum dan Humas Badan Urusan Administrasi Mahkamah Agung, 2015),hlm. 95-98. 
dakwaan yang diajukan oleh Penuntut Umum ke persidangan. Bagi Hakim surat dakwaan merupakan dasar untuk melakukan pemeriksaan dan menjatuhkan putusan kepada terdakwa sesuai dengan ketentuan yang didakwakan. Syarat- syarat untuk suatu dakwaan telah ditentukan secara limitatif dalam Pasal 143 KUHAP dengan ancaman batal demi hukum atau dapat dibatalkan apabila syarat- syarat tersebut tidak dipenuhi. Pasal 143 KUHAP merupakan hukum acara pidana yang bersifat tertutup, sehingga tidak dapat ditafsirkan, karena akan merusak due process of law dan melanggar hak-hak azasi seseorang.

Bagi penganut positivis, tidak dijadikannya korporasi sebagai terdakwa tapi turut dituntut dan dipidana maka dapat dikategorikan sebagai pelanggaran hukum acara sekaligus melanggar hak asasi manusia dari subjek hukum korporasi yang notabene memiliki hak untuk diperiksa selayaknya subjek hukum orang. ${ }^{33}$ Para hakim yang menolak mengabulkan tuntutan Jaksa Penuntut Umum tersebut didasarkan atas Perma Nomor 5 Tahun 2014 yang menjelaskan pengadilan harus menolak tuntutan tersebut dan menyarankan agar Jaksa Penuntut Umum mendakwa pihak ketiga terlebih dahulu dalam perkara tersendiri. Dalam konteksinibersesuaian dengan ketentuan dalam Pasal 6 Perma Nomor 5 Tahun 2014 yang menyebutkan bahwa uang pengganti hanya dapat dijatuhkan terhadap Terdakwa dalam perkara yang bersangkutan. Artinya prasyarat bahwa pidana tambahan berupa pembayaran uang pengganti hanya bisa dijatuhkan kepada pihak baik seseorang ataukah korporasi yang berstatus Terdakwa. Dengan kata lain bahwa yang tidak berstatus Terdakwa, meskipun turut dituntut dalam tuntutan Jaksa Penuntut Umum maka dilarang dipidana dengan pidana uang pengganti.

Sementara itu dalam perspektif hukum progresif, putusan pemidanaan korporasi ini sesungguhnya dalam rangka melindungi hak asasi manusia dari Terdakwa (orang) Pengurusnya yang tidak mungkin memiliki kemampuan mengembalikan kerugian keuangan negara yang telah masuk dalam keuntungan korporasi. Selain itu dari perspektif hak asasi manusia negara (masyarakat) memiliki hak untuk pengembalian kerugian keuangan negara dari perbuatan korupsi yang terbukti tersebut. Dalam konteks ini putusan pemidanaan yang demikian dikategori sebagai upaya penemuan hukum. Putusan pemidanaan korporasi dalam tindak pidana korupsi yang demikian sesungguhnya merupakan realitas dari fungsionalisasi penafsiran hakim. ${ }^{34}$ Karena dalam tinjauan filosofi pemidanaan yang bertujuan untuk memperbaiki keadaan yang rusak dari akibat tindak pidana korupsi yaitu pengembalian kerugian keuangan Negara, maka terobosan tafsir hakim tersebut dapat dikatakan menemukan relevansinya. Sebagaimana dinyatakan oleh Satjipto Rahardjo bahwa "oleh bangsa Indonesia, korupsi yang meluas dinamakan extra ordinary crime. Dan kita tidak berhenti pada pemberian nama yang menyeramkan itu, tetapi juga mengandung

33 Bettina Yahya, Pembuktian Tindak Pidana Korupsi yang Dilakukan Korproasi guna Pengembalian Kerugian Keuangan Negara, Disertasi, (Yogyakarta: Sekolah Pascasarjana Fakultas Hukum Universitas Gadjah Mada, 2018). hlm. 227-228.

$34 \quad$ Ibid., hlm. 228. 
makna memberantas dengan cara yang sesuai dengan keparahan korupsi". ${ }^{35}$

Sesungguhnya jika kembali pada istilah uang pengganti yaitu mengandung pengertian yang terkait bukan kepentingan perorangan atau individu, tetapi kepentingan publik atau bahkan kepentingan negara. Dalam hal itu dapat dikatakan criminal and punitive in their nature. Hal ini jelas berbeda sifatnya, misalnya saja dengan tuntutan ganti kerugian karena ditangkap, ditahan, dituntut, atau diadili, atau dikenakan tindakan lain tanpa alasan yang berdasarkan hukum, karena kekeliruan mengenai orang-nya, hukum yang diterapkan adalah Pasal 95 KUHAP. Masalahnya juga berbeda dengan gugatan ganti kerugian sebagai akibat perbuatan yang menjadi dasar dakwaan yang dapat digabungkan kepada perkara pidana (Pasal 98 KUHAP). Pada hal ini, yang terkait adalah kepentingan individu, bukan kepentingan Negara. ${ }^{36}$ Sementara kepentingan utama dari penerapan pidana uang pengganti adalah pemulihan kerugian keuangan Negara.

Sebagaimana teori social defence bahwa pemidanaan melalui uang pengganti itu tidak saja bernilai pembalasan tetapi sebagai sarana melindungi kepentingan masyarakat. ${ }^{37}$ W.P.J. Pompe menegaskan bahwa titik berat hukum pidana dalam perkembanganya saat ini adalah kepentingan umum atau kepentingan masyarakat. Hubungan hukum yang ditimbulkan oleh perbuatan sesorang yang menimbulkan dijatuhkannya pidana, bukanlah suatu hubungan yang bersifat koordinasi antara yang bersalah dengan yang dirugikan, melainkan hubungan subordinasi dari yang bersalah terhadap pemerintah yang ditugaskan untuk kepentingan rakyat. ${ }^{38}$ Oleh karena itu merupakan hal yang relevan bahwa penerapan pidana uang pengganti terhadap korporasi yang menguasai aset hasil tindak pidana korupsi dari pengurusnya, sudah selayaknya turut dituntut dan dipidana untuk mengembalikan kerugian keuangan Negarasebabjika hanyamengandalkan pidana uang pengganti terhadap pengurusnya justru tidak akan bisa terealisasi upaya optimal mengembalikan kerugian keuangan Negara $a$ quo pemulihan perekonomian nasional.

Selain itu menurut ajaran vicariousliability bahwa seseorang dimungkinkan harus bertanggung jawab atas perbuatan orang lain. Apabila jenis ini diterapkan pada korporasi berarti korporasi dimungkinkan harus bertanggungjawab atas perbuatan-perbuatan yang dilakukan oleh para pegawainya, kuasanya atau mandatarisnya yang bertanggungjawab kepada korporasi. Hal ini juga mendapatkan legitimasi dari Pasal 20 ayat (1) Undang-Undang Tipikor yang menyebutkan bahwa dalam hal tindak pidana korupsi dilakukan oleh atau atas nama suatu korporasi, maka tuntutan dan penjatuhan pidana dapat dilakukan terhadap korporasi dan atau pengurusnya. Frasa dan/atau dalam kalimat tuntutan dan penjatuhan pidana dapat dilakukan terhadap korporasi secara tersendiri ataukah bersamasama dengan pengurusnya, meskipun yang didakwakan sebagai pelaku korupsi adalah

\footnotetext{
35 Alkostar, Artidjo. Korelasi Korupsi Politik dengan Hukum dan Pemerintahan di Negara Modern (Telaah tentang Praktik Korupsi Politik dan Penanggulangannya), Jurnal Hukum Volume 16, (Oktober 2009), hlm. 170.

36 Krisna Harahap, Pemberantasan Korupsi Jalan Tiada jung, (Bandung: Grafitri, 2006), hlm. 6.

37 Muladi danBarda Nawawi Arif, Teori-Teori dan Kebijakan Pidana, (Bandung: Alumni, 1992), Hlm. 16.

38 Suhendar, Konsep Kerugian Keuangan Negara: Pendekatan Hukum Pidana, Hukum Administrasi Negara, dan Pidana Khusus Korupsi, (Malang: Setara Press, 2015), hlm. 7.
} 
pengurusnya. Jadi ketika pengurus diajukan sebagai Terdakwa dan dalam proses peradilan terbukti secara sah dan meyakinkan terjadi tindak pidana korupsi atas nama korporasi maka terhadap korporasinya dapat dituntutkan dan juga dipidanakan (termasuk dalam hal ini pidana uang pengganti). Dalam konteks ini sesungguhnya para hakim yang berpandangan bahwa korporasi dapat dipidana dengan uang pengganti meskipun tidak dijadikan Terdakwa adalah sah sesuai doktrin vicarious liability yang diakomodasi oleh Pasal 20 ayat (1) UndangUndang Tipikor.

Vicarious liability dapat terjadi dalam hal seseorang dapat dibebankan pertanggungjawaban pidana atas perbuatan orang lain apabila terdapat adanya pendelegasian (the delegation principle). Seorang majikan atau pemberi kerja dapat dipertanggungjawabkan atas perbuatan yang secara fisik dilakukan oleh pekerjaannya apabila menurut hukum perbuatan itu dipandang sebagai perbuatan majikan. ${ }^{39}$ Penerapan doktrin pertanggungjawaban pengganti (vicarious liability) ini diharapkan menjadi faktor yang dapat mencegah dan meminimalisasi terjadinya tindak pidana, baik tindak pidana yang dilakukan oleh orang perseorang maupun tindak pidana yang dilakukan oleh korporasi. ${ }^{40}$ Asas vicarious liability lebih mudah diterapkan karena tidak diperlu lagi mencari-cari siapa pelakunya (directing mind), apakah pelakunya sebagai actor seriusnya atau perbuatan pidananya, apakah ada kesalahan (mens rea), jadi pertanggungjawaban bisa dibebankan kepada korporasinya. ${ }^{41}$

Harus diakui bahwa ditetapkannya pengurus saja sebagai dapat dipidana ternyata tidak cukup. Dalam delik-delik ekonomi (termasuk korupsi) bukan mustahil denda yang dijatuhkan sebagai hukuman kepada pengurus dibandungkan dengan keuntungan yang telah diterima oleh korporasi dengan melakukan perbuatan itu, atau kerugian yang ditimbulkan dalam masyarakat, atau yang diderita oleh saingansaingannya, keuntungan dan atau kerugiankerugian itu adalah lebih besar daripada denda yang dijatuhkan sebagai pidana. Dipidananya pengurus tidak memberikan jaminan yang cukup bahwa korporasi tidak sekali lagi melakukan perbuatan yang telah dilarang oleh undangundang itu. ${ }^{42}$ Oleh karena itu pidana tambahan berupa kewajiban terhadap terpidana untuk membayar uang pengganti dengan jumlah maksimum sebesar jumlah harta benda yang diperoleh dari perbuatan yang dilakukannya serta dituntut dandikenakan pada setiap kasus tindak pidana korupsi sebagai salah satu upaya aparat penegak hukum untuk mengembalikan keuangan Negara ${ }^{43}$ atau perekonomian Negara, maka terhadap korporasi yang bersangkutan

39 Kristian, Hukum Pidana Korporasi: Kebijakan Integral (Integral Policy) Formulasi Pertanggungjawaban Pidana Korporasi di Indonesia, (Bandung: Nuansa Aulia, 2014), hlm. 68.

$40 \quad$ Ibid, hlm. 70.

41 Agus Budianto, Delik Suap Korporasi di Indonesia, (Bandung: Karya Putra Darwati, 2012), hlm. 215.

42 Dwidja Priyatno, Pertanggungjawaban Pidana Korporasi, Makalah disampaikan dalam Seminar Nasional tentang "Menjerat Korporasi Dengan Pertanggungjawaban Hukum" yang diselenggarakan oleh Ikatan Hakim Indonesia pada tanggal 24 Maret 2017 di Hotel Mercure Ancol Jakarta. hlm. 10.

43 Hendarman Supandji, Substansi Uang Penggantidalam Tindak Pidana Korupsi, Makalah Penataran TindakPidana Korupsi. (Jakarta: Puslitbang Kejaksaan Agung R.I. tanggal 5-6 Juli 2006), hlm.1. 
relevan untuk dikenakan pidana tambahan pembayaran uang pengganti. ${ }^{44}$

\section{Penutup}

Eksistensi pidana tambahan berupa uang pengganti terhadap korporasi dalam perkara tindak pidana korupsi diatur oleh Pasal 18 ayat (1) huruf b Undang-Undang Tipikor yang menyebutkan bahwa pembayaran uang pengganti yang jumlahnya sebanyak-banyaknya sama dengan harta benda yang diperoleh dari tindak pidana korupsi. Selanjutnya diatur pula oleh Pasal 6 Perma Nomor 5 Tahun 2014 yang menyebutkan bahwa uang pengganti hanya dapat dijatuhkan terhadap Terdakwa dalam perkara yang bersangkutan. Permasalahan dalam praktik muncul dimana Mahkamah Agung mengabulkan tuntutan Jaksa Penuntut Umum yaitu menjatuhkan pidana uang pengganti kepada korporasi yang tidak dijadikan Terdakwa. Dalam perspektif hukum progresif, putusan pemidanaan uang pengganti terhadap korporasi ini sesungguhnya dalam rangka melindungi hak asasi manusia dari Terdakwa (orang) Pengurusnya yang tidak mungkin memiliki kemampuan mengembalikan kerugian keuangan negara yang telah masuk dalam keuntungan korporasi. Selain itu pemidanaan progresif ini merupakan usaha untuk pemulihan kerugian keuangan Negara sebab jika hanya mengandalkan pidana uang pengganti terhadap pengurusnya justru tidak akan bisa terealisasi.

Perbedaan putusan pemidanaan uang pengganti terhadap korporasi yang tidak dijadikan sebagai Terdakwa dalam perkara korupsi didasari oleh perbedaan tafsir antar hakim sehingga memicu pro-kontra. Demi mewujudkan harmonisasi penerapan hukum maka pro-kontra ini harus diselesaikan melalui kesepemahaman bersama bahwa pendekatan hukum progresif perlu digunakan untuk pemulihan kerugian Negara melalui penjatuhan pidana uang pengganti terhadap korporasi yang menguasai aset hasil korupsi pengurusnya.

\section{Daftar Pustaka}

\section{Buku}

Adji, Indriyanto Seno, Korupsi dan Penegakan Hukum, (Jakarta: Diadit Media, 2009).

Biro Hukum dan Humas Badan Urusan Administrasi Mahkamah Agung, Kompilasi Penerapan Hukum Oleh Hakim dan Strategi Pemberantasan Korupsi, (Jakarta: Biro Hukum dan Humas Badan Urusan Administrasi Mahkamah Agung, 2015).

Budianto, Agus, Delik Suap Korporasi di Indonesia, (Bandung: Karya Putra Darwati, 2012).

Irianto, Sulistyowati dan Shidarta, Metode Penelitian Hukum (Konstelasi dan Refleksi), (Jakarta: Yayasan Pustaka Obor Indonesia, 2011).

Krisna Harahap, Pemberantasan Korupsi Jalan Tiada jung, (Bandung: Grafitri, 2006).

Kristian, Hukum Pidana Korporasi: Kebijakan Integral (Integral Policy) Formulasi Pertanggungjawaban Pidana Korporasi di Indonesia, (Bandung: Nuansa Aulia, 2014).

Kristiana, Yudi, Pemberantasan Tindak Pidana Korupsi Perspektif Hukum Progresif, (Yogyakarta: Thafamedia, 2016).

Manuain, Orpa Ganefo, Pertanggungjawaban Pidana Korporasi dalam Tindak Pidana Korupsi, Tesis, (Semarang: Magister Hukum Universitas Diponegoro, 2005).

Marzuki, Peter Mahmud, Penelitian Hukum (Jakarta: Kencana, 2014).

Muladi dan Barda Nawawi Arif, Teori-Teori dan Kebijakan Pidana, (Bandung: Alumni, 1992).

Sjahdeini, Sutan Remi, Pertanggungjawaban Pidana Korporasi, (Jakarta: Grafiti Pers, 2006).

44 Yudi Kristiana, Pemberantasan Tindak Pidana Korupsi Perspektif Hukum Progresif, (Yogyakarta: Thafamedia, 2016), hlm.64. 
Subekti dan R. Tjitrosudibio, Kamus Hukum, (Jakarta: Paramita, 1979).

Suhendar, Konsep Kerugian Keuangan Negara: Pendekatan Hukum Pidana, Hukum Administrasi Negara, dan Pidana Khusus Korupsi, (Malang: Setara Press, 2015).

Widyo Pramono, Pertanggungjawaban Pidana Korporasi Hak Cipta, (Bandung: Alumni, 2013).

Yahya, Bettina, Pembuktian Tindak Pidana Korupsi yang Dilakukan Korproasi guna Pengembalian Kerugian Keuangan Negara, Disertasi, (Yogyakarta: Sekolah Pascasarjana Fakultas Hukum Universitas Gadjah Mada, 2018).

\section{Makalah/Artikel/Prosiding/Hasil Penelitian}

Alkostar, Artidjo, "Korelasi Korupsi Politik dengan Hukum dan Pemerintahan di Negara Modern (Telaah tentang Praktik Korupsi Politik dan Penanggulangannya)," Jurnal Hukum Volume 16, (2009).

Alkostar, Artidjo, "Kedudukan dan Tanggung Jawab Pidana Korporasi dalam Tindak Pidana Korupsi" (disampaikan dalam seminar tentang Kedudukan dan tanggung jawab korporasi dalam tindak pidana korupsi, Jakarta Pusat, 15 Nopember 2016.

Prasetyo, Rudi, "Perkembangan Korporasi dalam Proses Modernisasi dan PenyimpanganPenyimpangannya", (disampaikan pada Seminar Nasional kejahatan Korporasi di FH UNDIP, Semarang, 23-24 November, 1989).

Priyatno, Dwidja, "Pertanggungjawaban Pidana Korporasi", (disampaikan dalam Seminar Nasional tentang Menjerat Korporasi Dengan Pertanggungjawaban Hukum yang diselenggarakan oleh Ikatan Hakim Indonesia, Jakarta, 24 Maret 2017.

Suhariyanto, Budi, "Progresivitas Putusan Pemidanaan terhadap Korporasi Pelaku Tindak Pidana Korupsi", Jurnal De Jure Volume 16 Nomor 2, (2016)

Suhariyanto, Budi, "Restoratif Justice dalam Pemidanaan Korporasi Pelaku Korupsi Demi Optimalisasi Pengembalian Kerugian Negara" Jurnal Rechtsvinding Volume 5 Nomor 3, (2016).
Suhariyanto, Budi, "Pertanggungjawaban Pidana Korporasi Berdasarkan Corporate Culture Model dan Implikasinya Bagi Kesejahteraan Masyarakat", Jurnal Rectsvinding Volume 6 Nomor 3(2017).

Supandji, Hendarman, "Substansi Uang Pengganti dalam Tindak Pidana Korupsi, Makalah Penataran Tindak Pidana Korupsi“,Puslitbang Kejaksaan Agung R.I. (2006)

Toruan, Henry Donald, "Pertanggungjawaban Pidana Korupsi Korporasi", Jurnal Rechtsvinding Volume 3 Nomor 3, (2014).

\section{Internet}

Nur Syarifah, "Mengupas Permasalahan Pidana Tambahan Pembayaran Uang Pengganti dalam Perkara Korupsi", www.leip.or.id (diakses 10 November 2017).

\section{Peraturan}

Undang-Undang Hukum Pidana (KUHP).

Undang-Undang Nomor 3 Tahun 1971 tentang Pemberantasan Tindak Pidana Korupsi.

Undang-Undang Nomor 31 Tahun 1999 tentang Pemberantasan Tindak Pidana Korupsi.

Undang-Undang Nomor 20 Tahun 2001 tentang Perubahan Atas Undang-Undang Nomor 31 Tahun 1999 Pemberantasan Tindak Pidana Korupsi.

Peraturan Mahkamah Agung Nomor 5 Tahun 2014 tentang Pidana Tambahan Uang Pengganti Dalam Tindak Pidana Korupsi.

Peraturan Mahkamah Agung Nomor 13 Tahun 2016 tentang Tata Cara Penanganan Perkara Tindak Pidana Oleh Korporasi.

Peraturan Jaksa Agung Republik Indonesia Nomor: Per-028/A/JA/10/2014 tentang Pedoman Penanganan Perkara Pidana Dengan Subjek Hukum Korporasi.

Peraturan Jaksa Agung Nomor: Per-013/A/ JA/06/2014 tentang Pemulihan Aset.

Surat Edaran Kejaksaan Agung RI Nomor B-036/A/ Ft.1/06/2009 perihal Korporasi Sebagai Tersangka/Terdakwa DalamTindak Pidana Korupsi. 